\title{
Residual sight-threatening lesions in leprosy patients completing multidrug therapy and sulphone monotherapy
}

\author{
T J FFYTCHE \\ St Thomas's Hospital, London
}

Accepted for publication 27 July 1990

\begin{abstract}
Summary An analysis of data derived from standardized surveys of the ocular findings in cross-sections of the leprosy population in 23 areas is presented. It shows that $24.3 \%$ of the patients completing multidrug therapy and $32.9 \%$ of those completing sulphone monotherapy have on-going eye problems which have the potential to lead to blindness or severe visual impairment. Most of the ocular complications involve the lids, cornea and anterior uveal tract, but a significant proportion of patients had cataract threatening vision.

If left unsupervised, many of these patients will develop major visual problems which could have been avoided. It is important that completion of systemic leprosy therapy should not be regarded as a guarantee that the eyes are safe, and that regular ocular supervision should be continued long after the patient has been classified as 'cured'.
\end{abstract}

\section{Introduction}

Leprosy is an important disease in many developing countries and its ocular complications contribute significantly to world blindness statistics. In a recent multicentre study between 4 and $7 \%$ of leprosy patients were found to be blind and between 6 and $10 \%$ had severe visual impairment.'

Four main mechanisms may cause blindness or severe visual impairment:

1 Lagophthalmos leading to exposure keratopathy.

2 Reduced or absent corneal sensation leading to corneal ulceration.

3 Acute or chronic iridocyclitis.

4 Cataract.

Lagophthalmos and corneal hypoesthesia may develop in all types of leprosy, whereas iris involvement occurs primarily in multibacillary disease. Cataract may be secondary to anterior segment damage, particularly iridocyclitis, but in most regions where leprosy is endemic, cataract is the commonest cause of blindness in the general community and its association with leprosy is often coincidental.

In many countries leprosy patients now receive multidrug therapy (MDT) according to recommendations by the WHO in its report on chemotherapy of leprosy for control 
programmes. ${ }^{2}$ The dosage of drug combinations and the duration of treatment have been established, and the WHO has set down guidelines for the registering of patients and also for their discharge from care after completion of MDT. It should be recognized however that ocular complications of leprosy may occur long after a so-called 'cure' has been achieved, some may be undetectable except by sophisticated ophthalmic examinations, and damage sustained to the eyes during the early stages of the disease can progress and may not be reversible.

The purpose of this paper is to draw attention to the fact that a significant proportion of patients who have completed their therapy and are therefore eligible for discharge have ongoing eye problems which have the potential to lead to blindness. Much of this blindness is preventable provided that there is continued ophthalmic supervision and appropriate therapy.

\section{Present study}

Since 1983 LEPRA has organized a world-wide survey on the ocular complications of leprosy in randomly selected cross-sections of the leprosy population. The protocol includes the recording of details of the disease, its duration, status and therapy as well as a simple objective examination of the lids and anterior parts of the eye-the structures affected by leprosy. ${ }^{2}$ Over 3500 patients have been recruited into the study and examined under standardized conditions in 33 centres scattered throughout the world.

Following the institution of MDT in 1982 patients began to be released from control in the mid-1980s and their numbers continue to increase as more centres follow the WHO guidelines.

Since 1986 a total of 2321 patients have been examined in 23 centres (Table 1); 524 had completed their course of therapy and had negative skin smears. Of these $354(15 \cdot 2 \%)$ had completed MDT and $170(7 \cdot 3 \%)$ had completed monotherapy with sulphones. These two groups of patients were examined in order to determine the prevalence of blindness, severe visual impairment and potentially sight-threatening lesions (PST).

Eye problems were regarded as significant if they were thought likely to lead to blindness or severe visual impairment. The concept of PST lesions, originally introduced by Lamba et $a l .{ }^{4}$ has been modified slightly. They are a particularly important feature of the disease, since they are often amenable to relatively simple preventive therapy. Routine supervision of continued ocular therapy or measures to prevent blindness may not

Table 1. Centres studied in LEPRA surveys since 1986

\begin{tabular}{ll} 
South America & Brazil, Bolivia (2) \\
Africa & Tanzania, Ethiopia, Kenya (2), Nigeria, Malawi \\
South-East Asia & Thailand (2), Hong Kong \\
$\begin{array}{l}\text { South Pacific } \\
\text { Indian sub-continent } \\
\text { North* }\end{array}$ & $\begin{array}{l}\text { Tonga, Fiji, Solomon Islands, Australia } \\
\text { South* }\end{array}$ \\
& $\begin{array}{l}\text { Simla, Bihar, Nepal, Bangladesh } \\
\text { Ahmedabad, Maldive Islands, Trivandrum }\end{array}$ \\
\hline
\end{tabular}

\footnotetext{
${ }^{*}$ For the purposes of this study the Indian sub-continent was divided into north and south by the Tropic of Cancer.
} 
however be available in many areas of the world, and it is important therefore for leprologists to be able to anticipate ocular problems by identifying those patients at risk.

Ocular complications of leprosy have a variety of manifestations and many are easily detected by a simple and systematic eye examination and can be treated effectively by nonophthalmologists. ${ }^{5}$ The following components of the routine standardized eye examination in the 524 patients completing MDT and monotherapy have been recorded and analysed:

\section{Blindness and severe visual impairment}

Using a standard Snellen's E Chart at $6 \mathrm{~m}$, patients with corrected visual acuity of less than $3 / 60$ in the better eye were recorded as blind. Those with acuity less than $6 / 60$ in the better eye were recorded as having severe visual impairment. All causes of blindness were included in these two groups.

\section{Lid involvement}

Significant lid involvement was recorded when there was lagophthalmos with incomplete corneal cover on forced lid closure. Under these circumstances the cornea is at risk from trauma and infection, especially if corneal sensation is reduced or absent.

\section{Corneal involvement}

Significant corneal involvement was defined as absent corneal sensation or corneal opacities reducing vision to below the level of 6/36. Corneal opacities are not reversible and are more likely to progress with age. In addition a hypaesthetic and already compromised corneal epithelium renders the eye more susceptible to recurrent damage, which in an insensitive eye, may not be noticed by the patient at a time when it could be treated.

\section{Iris involvement}

Significant iris involvement was recorded in those patients with either a non-reacting pupil less than $2 \mathrm{~mm}$ in diameter or an irregular or eccentric pupil with detectable synechiae. In lepromatous leprosy, chronic iris changes with progressive miosis and unreacting pupils is a common cause of visual disability and tends to be overlooked since it is often symptomless and requires sophisticated instrumentation, such as a slit-lamp, for diagnosis. An irregular pupil with synechiae indicates a previous episode of acute iritis, carrying the risk of further attacks, secondary glaucoma or cataract. An eccentric pupil may also be a feature of ciliary body involvement.

\section{Cataract}

Cataract was considered to be significant if the visual acuity was less than $6 / 36$ and there were visible lens opacities or an absent red reflex. This is the commonest cause of blindness in areas where leprosy is endemic. It may be difficult to diagnose in the presence of a small pupil, but since damage to the post-equatorial segment of the eye rarely occurs in leprosy, 
diminished vision with an absent red reflex is more than likely to be due to cataract and therefore represents a developing problem that can only be resolved by surgery.

A patient with one of the above conditions was considered to have a potentially sightthreatening lesion irrespective of whether one or both eyes were involved. Many patients had multiple problems of the lids and eye and when there was more than one complication, the one with the most affect on vision was recorded. Patients who had cataract without any other signs of ocular leprosy were recorded separately.

\section{Results}

Cross-sections of 23 leprosy populations were studied and the groups divided into six geographic regions shown on Table 1. In Bolivia, Kenya and Thailand more than one survey has been undertaken, but the areas chosen have always been geographically distant from each other so that no overlap of patients has occurred.

\section{AFFECTED PATIENTS}

Tables 2 and 3 show the analysis of patients who had completed MDT and sulphone

Table 2. Analysis of patients who had completed multidrug therapy

\begin{tabular}{lcccccc}
\hline & & & & \multicolumn{2}{c}{ Visual acuity } \\
\cline { 5 - 6 } Region & $\begin{array}{c}\text { Total } \\
\text { examined }\end{array}$ & $\begin{array}{c}\text { Completed } \\
\text { therapy }\end{array}$ & $\begin{array}{c}\text { Affected } \\
\text { patients }\end{array}$ & $<3 / 60$ & $<6 / 60$ \\
\hline South America & 223 & 1 & $0(0 \%)$ & 0 & 0 \\
Africa & 509 & 45 & $9(20 \cdot 0 \%)$ & 3 & 4 \\
South-East Asia & 266 & 66 & $18(27 \cdot 3 \%)$ & 2 & 2 \\
South Pacific & 285 & 13 & $4(30 \cdot 7 \%)$ & 0 & 0 \\
North India & 610 & 32 & $3(9 \cdot 4 \%)$ & 0 & 0 \\
South India & 428 & 197 & $52(26 \cdot 4 \%)$ & 19 & 25 \\
\hline Total & 2321 & 354 & 86 & 24 & 31 \\
& & $15 \cdot 2 \%$ & $24 \cdot 3 \%$ & $6 \cdot 8 \%$ & $8 \cdot 8 \%$ \\
\hline
\end{tabular}

Table 3. Analysis of patients who had completed sulphones

\begin{tabular}{|c|c|c|c|c|c|}
\hline \multirow[b]{2}{*}{ Region } & \multirow{2}{*}{$\begin{array}{c}\text { Total } \\
\text { examined }\end{array}$} & \multirow{2}{*}{$\begin{array}{l}\text { Completed } \\
\text { therapy }\end{array}$} & \multirow{2}{*}{$\begin{array}{l}\text { Affected } \\
\text { patients }\end{array}$} & \multicolumn{2}{|c|}{ Visual acuity } \\
\hline & & & & $<3 / 60$ & $<6 / 60$ \\
\hline South America & 223 & 15 & $1(6 \cdot 7 \%)$ & 0 & 0 \\
\hline Africa & 509 & 52 & $25(48 \cdot 1 \%)$ & 0 & 0 \\
\hline South-East Asia & 266 & 29 & $9(31 \cdot 0 \%)$ & 1 & 2 \\
\hline South Pacific & 285 & 36 & $13(36 \cdot 1 \%)$ & 3 & 3 \\
\hline North India & 610 & 13 & $4(30 \cdot 8 \%)$ & 0 & 1 \\
\hline South India & 428 & 25 & $4(16 \cdot 0 \%)$ & 4 & 4 \\
\hline \multirow[t]{2}{*}{ Total } & 2321 & 170 & 56 & 8 & 10 \\
\hline & & $7 \cdot 3 \%$ & $32 \cdot 9 \%$ & $4 \cdot 7 \%$ & $5 \cdot 9 \%$ \\
\hline
\end{tabular}


monotherapy and demonstrate that there was a considerable variation in the different regions studied. The percentage of those off MDT who were found to have significant ocular involvement also varied from $30.7 \%$ in the South Pacific area to $9.4 \%$ in North India with an average of $24.3 \%$ overall. In patients completing sulphones the overall average of those with sight-threatening conditions was $32.9 \%$ with a variation of from $6.7 \%$ in South America to $48 \cdot 1 \%$ in Africa.

\section{BLINDNESS AND SEVERE VISUAL IMPAIRMENT}

Several patients in this series were already blind or had severe visual impairment $-6 \cdot 8 \%$ blind and $8 \cdot 8 \%$ with severe visual impairment in the group off MDT, and $4 \cdot 7 \%$ blind and $5.9 \%$ with severe visual impairment in the group completing sulphone monotherapy. (In this analysis the blind patients are included in the numbers of those with severe visual impairment.)

\section{SIGHT-THREATENING LESIONS}

The patients in this study were divided into two main groups according to the WHO modification of the Ridley-Jopling classification: ${ }^{6}$

1 Paucibacillary (PB) - where skin smears were negative at all sites. This included patients considered indeterminate, tuberculoid (TT) and borderline tuberculoid (BT) under the Ridley-Jopling classification.

2 Multibacillary (MB) - where skin-smears were positive. These included mid-borderline (BB), borderline lepromatous (BL) and lepromatous (LL) patients.

Eighty-six patients completing MDT were considered to have sight-threatening lesions: $37 \cdot 2 \%$ were found to have significant lid problems, $39 \cdot 5 \%$ had evidence of corneal disease threatening sight, and $23 \cdot 3 \%$ had complications relate to iridocyclitis (Table 4 ). Not surprisingly over $60 \%$ of these patients had multibacillary leprosy which is known to be associated with a higher prevalence of eye complications than other forms. ${ }^{7}$

In 56 patients who had completed sulphone therapy and had significant ocular involvement, $41 \cdot 1 \%$ had problems related to lid function, $42 \cdot 8 \%$ had evidence of corneal disease and $16 \cdot 1 \%$ had iris involvement (Table 5). In this group the percentage of affected patients with multibacillary and paucibacillary disease were comparable.

Table 4. Total affected off $\mathrm{MDT}=86$

\begin{tabular}{lcccc}
\hline & Total & Lids & Cornea & Iris \\
\hline MB & $52(60 \cdot 5 \%)$ & 17 & 20 & 15 \\
PB & $30(34 \cdot 9 \%)$ & 15 & 14 & 1 \\
Unknown & $4(4 \cdot 6 \%)$ & 0 & 0 & 4 \\
\hline Total & 86 & 32 & 34 & 20 \\
& & $37 \cdot 2 \%$ & $39 \cdot 5 \%$ & $23 \cdot 3 \%$ \\
\hline
\end{tabular}


Table 5. Total affected off sulphones $=56$

\begin{tabular}{lcccc}
\hline & Total & Lids & Cornea & Iris \\
\hline MB & $25(44 \cdot 6 \%)$ & 7 & 11 & 7 \\
PB & $22(39 \cdot 3 \%)$ & 11 & 10 & 1 \\
Unknown & $9(16 \cdot 1 \%)$ & 5 & 3 & 1 \\
\hline Total & 56 & 23 & 24 & 9 \\
& & $41 \cdot 1 \%$ & $42 \cdot 8 \%$ & $16 \cdot 1 \%$ \\
\hline
\end{tabular}

\section{CATARACT}

A separate analysis of the prevalence of cataract without any ocular signs of leprosy showed that, out of the 354 patients who had completed MDT, 66 (18.6\%) had lens opacities reducing the visual acuity to below the level of 6/36. Multibacillary patients formed $75 \cdot 7 \%$ of this group and paucibacillary $24 \cdot 3 \%$. Out of the 170 patients who had completed sulphone monotherapy a total of $28(16 \cdot 4 \%)$ had a similarly reduced level of visual acuity due to cataract. Multibacillary patients formed $42.9 \%$ of the group, paucibacillary $46.4 \%$ and in $10.7 \%$ the type of leprosy was unknown.

\section{Discussion}

In 1982 the WHO Study Group published its recommendations for chemotherapy in leprosy control programmes. This report was stimulated by the recognition of poor drug compliance in many patient populations and the increasing emergence of primary and secondary dapsone resistance in all forms of the disease.

The recommended therapeutic regime for PB patients was dapsone $100 \mathrm{mg}$ daily, unsupervised, plus rifampicin $600 \mathrm{mg}$ once monthly, supervised for 6 months. All therapy was discontinued after this course. The regime for MB patients was dapsone $100 \mathrm{mg}$ daily plus clofazimine $50 \mathrm{mg}$ daily, unsupervised, plus rifampin $600 \mathrm{mg}$ and clofazimine $300 \mathrm{mg}$ once monthly, supervised. This regime should be continued for at least 2 years and preferably until the patient became smear-negative, when anti-leprosy treatment could be stopped.

The geographic variations in numbers of patients completing treatment in this study reflect local policies on the timing of the commencement of MDT, and it is to be expected that over the next few years many more patients will fall into this category in all areas.

No specific guidelines for ophthalmic supervision after completion of MDT were set up, although it was recommended that MB patients remain within control for a further five years and PB patients for two years. However in practice many patients may be taken off the leprosy register and discharged completely from further care. With the recognition that completion of therapy holds no guarantee of total cure or safeguard against further relapses, and that a considerable number of patients will have residual disability problems, several centres are evolving 'care after cure' policies. But in many others, where staffing levels among trained leprosy workers may be inadequate, de-registration and release from control is the accepted policy after completion of MDT or monotherapy.

The prevalence of blindness and severe visual impairment in both these groups of patients completing therapy conform with the more general prevalence studies for crosssections of leprosy populations previously reported ${ }^{8}$ There is a higher prevalence of 
blindness $(6 \cdot 8 \%)$ and severe visual impairment $(8 \cdot 8 \%)$ in the group off MDT than in the group off sulphone therapy, where blindness was found in $4.7 \%$ and severe visual impairment in $5.9 \%$. The difference between these two sets of figures reflect the fact that the majority of patients in the MDT group had the multibacillary form of the disease and were therefore more likely to have serious eye problems. In addition many of the old relapsed dapsone-resistant patients may have been switched to MDT because of repeated reactions which also carry an increased risk to vision. In the sulphone group by contrast there was a more even distribution between MB and PB patients, the latter being less susceptible to ocular damage.

From the ophthalmic point of view there are a number of conditions which, if present in the eye and not monitored or treated carefully, may well lead to blindness. Impairment of lid closure, especially if associated with poor corneal sensation, can lead to corneal ulceration, opacification and even perforation. This can be prevented by adequate attention to lid care and corneal protection. In this study lid and corneal damage were each seen in over a third of the patients completing MDT and sulphone monotherapy and there was no statistical difference between $\mathrm{MB}$ and PB cases. An examination of lid function and corneal sensation would therefore seem to be essential in all patients about to be discharged from control.

The presence of active or residual iris disease may render an eye more susceptible to acute and chronic glaucoma and secondary cataract, and an asymptomatic chronic lowgrade iridocyclitis may persist in patients with lepromatous leprosy long af ter they have been classified as cured. The latter will eventually produce a miotic pupil, resistant to conventional dilatation, and often associated with a profound ocular hypotension which may eventually lead to a phthisical eye. Damage to the iris and ciliary body occurs almost exclusively in MB cases and was seen in about a fif th of patients completing therapy. Many of the clinical signs are difficult to detect without sophisticated instruments and experience and the condition is therefore likely to be underdiagnosed, especially as vision may not be significantly affected until late in the disease. Leprosy workers should therefore be alert to this risk and should pay special attention in MB cases to pupil changes such as alterations in its size, shape and reactions.

Cataract itself is a common condition in all of the areas studied and is the major cause of blindness. It occurred in the absence of any ocular signs of leprosy in $18.6 \%$ of patients completing MDT of whom $75 \%$ had multibacillary disease. In those patients completing sulphone monotherapy significant cataract was found in $16.4 \%$, but the ratio between multibacillary and paucibacillary patients was almost even. In the absence of any other eye signs these cataracts must be regarded as coincidental, but the high prevalence of the condition in MB cases completing MDT is an interesting observation which if confirmed in future studies reopens the question as to whether 'leprosy' cataracts can occur and merits further investigation. ${ }^{9}$ Sadly, because of the stigma attached to the disease, in many regions the leprosy patient with cataract may not receive the surgical services offered to other members of the population.

The results of these combined surveys show that $24.3 \%$ of patients completing MDT, who might well be released from control and therefore from supervision, have on-going eye problems that are potentially sight-threatening. In addition $32.9 \%$ of patients completing monotherapy have similar evidence of long-term ocular damage. Many patients also have cataract causing significant visual impairment and these will inevitably add to the increasing reservoir of blind leprosy patients whose only chance of restoration of vision is surgery. 
Although patients with major ophthalmic problems are likely to remain under care and supervision, those with potentially sight-threatening lesions who have few visual symptoms but who form an equally important group, may well be discharged.

Leprosy patients, who may already have severe sensory and motor disabilities, require special attention if they have additional problems with vision, regardless of whether they are caused by the disease or not. It is of great importance for the welfare of these patients that these problems should be rectified by surgery if possible or at least modified by optical aids. The leprosy patient with impaired sight is ill-equipped to care for the eyes and limbs and is often entirely dependent on outside help, and may be at greater risk of further general complications. The completion of therapy and possible consequent discharge from ophthalmic supervision may lull the patient into a false sense of security, particularly since many early ocular problems can go undetected and symptoms may be minimal.

These results emphasize the importance of continued ophthalmic care for patients who have completed MDT or dapsone monotherapy. Failure to re-examine the eyes at regular intervals is likely to lead to an unacceptably high level of eventual visual impairment, much of which could be avoided or treated if detected early enough and referred for appropriate therapy. A bacteriological 'cure', as defined by the existing WHO recommendations and as practised in many centres, gives no guarantee that future ocular problems have been avoided. Indeed if these figures are representative of cases being released from control, they highlight an important logistic problem for leprosy workers, suggesting that in certain areas as many as one in five leprosy patients released from control may harbour sight-threatening lesions that can eventually lead to blindness.

\section{Acknowledgment}

None of these studies could have taken place without the conscientious contributions made by the 39 final-year medical students who carried out these surveys, often under conditions of difficulty and hardship, and who should rightly be listed as co-authors.

This work has been generously supported throughout by LEPRA and I would like to thank Dr R J W Rees and Dr M F R Waters for their continued advice and encouragement.

\section{References}

1 Courtright P, Johnson GF. Prevention of Blindness in Leprosy. Publ. International Centre for Eye Health, 1988.

2 World Health Organization Study Group. Chemotherapy of Leprosy for Control Programmes. WHO Technical Report Series No. 675, Geneva, 1982.

${ }^{3}$ ffytche TJ. A computer form to aid in the collection of data on the ocular complications of leprosy. Lepr Rev, 1983; 54: 271-81.

${ }^{4}$ Lamba PA, Santoshkumar D, Arthanariswaran R. Ocular Leprosy: A New Perspective. Lepr India, 1983; 55: 490-4.

5 Brand MB. Care of the eye in Hansen's Disease. 2nd ed. Carville: USA. 1987.

${ }^{6}$ Ridley DS, Jopling WH. Classification of Leprosy According to Immunity. Int J Lepr, 1966; 34: $255-73$.

${ }^{7}$ Brand MB, ffytche TJ. Eye Complications in Leprosy. In: Leprosy, Hastings RC, (ed), Churchill-Livingstone, 223-42. 1985.

8 ffytche TJ. Blindness in leprosy—a forgotten complication. Aust. New Zeal. J Ophthal, 1989; 17: 257-60.

9 Choyce DP. The diagnosis and management of ocular leprosy. Brit J Ophthal, 1961; 53: 217-23. 


\section{Lésions restantes qui menacent la vue chez des patients ayant completé les cours thérapeutiques à drogues multiples et de monothérapie de sulphone}

\section{T J FFYTCHE}

Sommaire - Une analyse est présentée ici des données provenant des sondages normalisés des résultats oculaires obtenus à partir des échantillons de la population de lèpre en 23 zones. Les résultats de cette analyse montrent qu'un $24,3 \%$ des patients qui ont complété la thérapie à drogues multiples et un $32,9 \%$ de ceux qui ont complété la monothérapie de sulphone ont des problèmes des yeux persistants qui peuvent potentiellement arriver à produire la cécité ou un grave affaiblissement visuel. La plupart de ces complications oculaires impliquent les paupières, la cornée et le tractus uveal antérieur, mais chez une proportion considerable des patients la vue était menacée par des cataractes.

Sans supervision, beaucoup de ces patients commenceront à avoir des problèmes majeurs de vue qui auraient pu être évités. Il est important de ne pas regarder le fait de compléter la thérapie systématique de lèpre comme assurance que les yeux du patient soient hors de danger, et de continuer la supervision oculaire régulière bien aprés avoir classifié le patient comme "complètement gueri".

\section{Lesiones post-recuperativas que amenazan la vista de pacientes tras cumplir la terapia multimedicinal o la monoterapia de sulfona}

\section{T J FFYTCHE}

Resumen - Se presenta un análisis de datos obtenidos a partir de estudios normalizados de los resultados oculares en una sección representativa de la población de enfermos de lepra en 23 zonas. Muestra que el $24,3 \%$ de los pacientes que han completado el tratamiento de drogas múltiples y el $32,9 \%$ de aquellos que han completado la monoterapia de sulfona tienen problemas de ojos que persisten y pueden potencialmente llegar a producir la ceguera o graves impedimentos visuales. La gran parte de estos problemas están relacionados con los párpados, la córnea y el tracto uveal anterior, sin embargo, una proporción importante de pacientes estaba en peligro de perder la vista por cataratas.

Sin supervisión, muchos de estos pacientes desarrollarán graves problemas de vista que podrían haberse evitado. Es importante el no suponer que el completar una terapia sistemática de lepra sea garantía de que los ojos del paciente queden a salvo, y que la supervisión regular de los ojos del paciente debe de continuar mucho tiempo después de clasificarlo médicamente como "completamente curado". 